\title{
CYCLES OF NATIONALISATION AND PRIVATISATION, AND THE ROLE OF THE STATE IN IRELAND*
}

\author{
Annamária ARTNER \\ (Received: 28 January 2017; revision received: 2 May 2017; \\ accepted: 25 May 2017)
}

The article examines how the roles of state institutions and state owned enterprises have been changed in Ireland since its independence, with special regard to the role of state ownership and crisis management. The history of planning and social partnership, the courses of nationalisation and privatisation and the problem of damaging the state are discussed as well. The author concludes that the crisis has not resulted in the strengthening of the developmental or welfare role of the state, the evolution of a "developmental welfare state" has become less likely in Ireland in the course of crisis management. Another lesson is that the state can manage certain bad assets of the private sector in a way that yields a profit to the public. There are other costs of the crisis management, however, which are to be paid by the people and result in a decrease of state ownership and a shrinking of the welfare systems.

Keywords: developmental state, Ireland, nationalisation, privatisation, state-owned enterprises, varieties of capitalism

JEL classification indices: G01, H10, H12, H81, L3, O2, P110

* This research was supported by the Hungarian Scientific Research Fund (OTKA), Grant No. 112069.

Annamária Artner, Senior Research Fellow at the Centre for Economic and Regional Studies, HAS Institute of World Economics and Habil. Professor at King Sigismund University, Budapest. E-mail: artner.annamaria@krtk.mta.hu 


\section{INTRODUCTION}

Due to the global economic crisis in 2008, state intervention has strengthened in increasingly more countries and the debate about the role of the state in the society has gained momentum. Now, almost a decade after the outbreak of the crisis and after years of bailouts, adjustment programmes, and austerity policies, it is worth raising the question of whether or not the policies of governments have really changed. To answer this question, the examination of special cases seems to be useful. This study is one of them. In the following, we shall examine how the role of the state changed in Ireland in the last decades, with a special focus on the courses of nationalisation and privatisation and the present situation after a relatively successful crisis management. ${ }^{1}$

The article is organised as follows. Firstly, a short history of the role of the state in the economic development of Ireland is presented that reflects the historical dominance of the free market policy in the country (Section 1). This is followed by a closer look at the history of state planning and the emergence, results, and limits of the social partnership that characterised the Irish developmental path in Section 2 and an overview of the role of the state ownership in Section 3. The courses of privatisation and nationalisation will be described in Section 4, while the problems of corruption and fraud related to the crisis and its management are illustrated in Section 5. The article ends with concluding remarks.

Our first conclusion is that the market economy needs the assistance of the state from time to time, albeit this assistance differs according to the specificities of countries. For a country such as Ireland, whose economy is well integrated into the global value chains and networks of transnational corporations, the role of the state is increasingly confined to the formulation and maintenance of a sound and reliable business climate that serves profit generation and to the management of the crises of capital accumulation, acting in this case as a lender of last resort. After the successful crisis management, the role of the Irish state weakened further, even relative to the pre-crisis situation. The second conclusion is that the state can manage the bad assets taken over from the private sector in a way that yields a profit to the public. There are, however, other costs of crisis management that are borne by the people and result in a decrease of state ownership and a shrinking of welfare systems.

1 Unless stated otherwise, economic data are taken from Eurostat. 


\section{THE HISTORICAL DOMINANCE AND EVOLUTION OF THE FREE MARKET POLICY}

The nature and policy orientation of the Irish state have always been actively debated in the literature, in line with the changing role of governments in the changing global economic environment. Accepting Esping-Andersen's classification of welfare regimes - conservative/corporatist, liberal/residual, and socialdemocratic (Esping-Andersen 1990) - and supplementing it with a reference to the influence of the Roman Catholic church in Ireland, some authors named Ireland a "Catholic corporatist" state (Adshead - Millar 2003). However, those definitions that aim at specifying the role of the state after the metamorphosis of the welfare state seem to be more popular. Ó Riain (2000) described the Irish state as a "flexible developmental state", the National Economic and Social Council of Ireland (NESC) defines it as a "flexible networked developmental state", where "a web of agencies and policies ... create the conditions in which international enterprises locate in Ireland and Irish enterprises connect with global markets" (NESC 2005: ix). Kirby $(2002,2009)$ speaks about a "competition state" and Considine - Dukelow (2010) call the Irish state as an "underdeveloped welfare state". All of these definitions refer to a state that subordinates social policy to the needs of economic efficiency, promotes flexibility, and "an activist (or activating) social policy rather than passive social transfers" (Boyle 2005: 16).

Ireland has never experienced an all-round welfare state. The state has always focused on education and public housing, placing less emphasis on other social services such as healthcare or the mitigation of poverty (Teague - Murphy 2004). This is likely due to the geographical location and the historical development of the country that have hammered out a peripheral, underdeveloped, and dependent economy, a situation that has left hardly any real alternative for the governments than to open the economy to the world market, to serve the interests of inward foreign capital investments, and to rely on their ability to create employment and increase the income of the originally very poor population.

Before gaining independence from the United Kingdom in 1922, Ireland had pursued a free-trade policy introduced by the UK. This course was maintained in the following decades as well when the Anglo-Irish trade war (1932-1938) after the Great Depression put an end to it. The conflict broke out because the Irish Free State refused to continue reimbursing Britain with land annuities from the "soft loans" that, before Irish independence, the British government granted to the Irish tenant farmers to allow them to buy out their farms from landlords. This six-year trade war caused more harm to the poor Ireland than to the wealthy UK. The unique era of protectionism in Ireland emerged in these years and lasted until the late 1950s. This period did not result in a meaningful socio-economic 
development, and neither could it curb the net emigration that began in the 1840s. In order to deal with these problems, a change in economic policy was needed (Murphy 2000; Encyclopaedia Britannica; Bielenberg - Ryan 2013).

The turn from import substitution to export-orientated policy occurred in 1958, when the series of the subsequent Programmes for Economic Expansion were launched (the programmes are discussed in the next section). In 1961, Ireland applied for membership in the European Economic Community (the EEC, as the European Union was called at that time). The actual liberalisation of trade began a few years later (1963-1964) and in 1965, the Anglo-Irish Free Trade Agreement was signed (Bielenberg - Ryan 2013). Thanks to this, there was an upswing in the export of goods and services that supported economic growth in the ensuing decades.

The liberalisation of the economy coincided with the modernisation of certain social institutions. In 1967, the system of secondary education was introduced; in the 1960s and 1970s, women's position began to improve - although an equal pay directive and the Employment Equality Act were adopted only in 1975 and 1977, respectively, years after joining the EEC (1973). Politically sensitive issues such as contraception, the role of the Catholic Church in society, and the possibility of divorce were being discussed openly. Therefore, the influence of Catholic Church on society has declined to some extent, which has given additional impetus to socio-economic development via, among others, women's growing social activity (Encyclopaedia Britannica).

Since 1973, EEC membership has supported socio-economic development firstly by enforcing the adaptation of European social standards such as political liberalism, gender emancipation, and social partnership. For example, the National Economic and Social Council (NESC), which embodies the representatives of employees' and employers' and the farming organisations, was established in 1973 with the task of advising the Taoiseach (Prime Minister) on strategic socio-economic and environmental policy issues. EEC membership meant financial assistance as well. The financial transfers arriving in Ireland from the structural and cohesion funds and the budget of the Common Agricultural Policy accounted for about 6\% of the Irish GDP per annum between 1989 and 1999 (Barry 2003: 405).

In the 1980s, the economy witnessed a protracted crisis with declining employment, falling living standards, and massive net emigration. Governments tried to help the situation with increasing public spending, but failed to reach the desired results. By 1986, public deficit grew over $10 \%$, public debt rose to more than $120 \%$ of the GDP, and the unemployment reached almost 17\% (EC 1998; Barry 2003). 
Despite the growing integration into the international economy and the massive financial support from the EEC, Ireland could not catch up with the developed European countries for decades. In 1960, measured in purchasing power standard (PPS), the Irish per capita GDP reached $57 \%$ of the average of the six founder nations of the EU and increased to only $60 \%$ by $1988 .{ }^{2}$ At the end of the 1980 s, Ireland was still one of the poorest countries of the EEC, only a slightly more developed than Greece.

However, in 1986, after a couple of unsuccessful stabilisation programmes, the Irish social partners, in the framework of the NESC, managed to hammer out a strategy (Strategy for Development, NESC 1986) that proved to be successful. On the basis of this strategic document, the Programme for National Recovery (PNR) 1987-1990 was elaborated. In 1987, both institutional reforms and a fiscal consolidation were launched (Farkas 1999). The PNR was the first national development programme that determined the pace of increase of wages for the following three-year programming period. The PNR was followed by similar threeyear plans that all included the rates of yearly wage increases. The government cut public spending substantially and reduced taxes as well. In fact, the moderation of wages could be carried out in return for income tax concessions. Thanks to this, the three-year agreements on pay rises were advantageous for all actors of the market: they insured relative modest increase of labour costs for employers on the one hand, while, with the concomitant tax reductions, they guaranteed an increase of incomes for employees on the other.

The consolidation of public finances was necessary, but would not have been sufficient for an economic recovery without beneficial external factors. Exports were fuelled first by the upswing of the British economy thanks to the major tax cuts in the United Kingdom in 1986, 1987, and 1988 (Giles - Johnson 1994), and later, from the mid-1990s, by the information technology boom of the United States. The increase of exports was due mainly to the American and British transnational companies (TNC). These firms preferred to choose Ireland as a location since the 1960s because of the low corporate taxes. In 1986, there was almost twice as much foreign direct investment (FDI) per person from the US in Ireland than in the UK, and almost six times more than in other EU countries. These ratios increased to three times and almost nine times, respectively, by the end of the $20^{\text {th }}$ century (Crafts 2008: 3). To attract even more investors, in 1987 the Irish government established the International Financial Service Centre that offered incentives, among them $10 \%$ corporation tax rate for manufacturing, to foreign companies to locate offices in Dublin.

2 Own calculations based on EC (1998, Table 6). 
The period of solid growth began after 1987, but the years of the "Celtic Tiger" followed only years later (1994-2002). Until the end of the century, growth surpassed $5 \%$, and in some years, it was over $10 \%$. Foreign companies intensified their activities, exports increased, while unemployment fell from $16.6 \%$ in 1987 to less than $3.9 \%$ in 2001 .

In the 1990s, profits grew at a spectacular pace, much faster than wages, the rise of which was limited by the three-year plans. As a study of the Central Statistical Office of Ireland stated, the situation in the 1990s was similar to that of the 1950s: profits were over $80 \%$ of wages. The only difference was that in the $1950 \mathrm{~s}$, almost $60 \%$ of profits derived from agriculture, while in the $1990 \mathrm{~s}$, the share of agriculture was already overtaken by manufacturing and services (dominated by foreign-owned companies) and by other forms of self-employment. In the half-century period between 1949 and 1999, the share of consumption gradually lessened among the components of GDP from around $80 \%$ at the mid-century to below $60 \%$ at the end of it and to just over $40 \%$ in 2016 and gave its place to exports which grew to more than $80 \%$ of the GDP around the Millenium and was over 120\% of it in 2016 (Redmond 2000: 89-90; CSO Ireland online database).

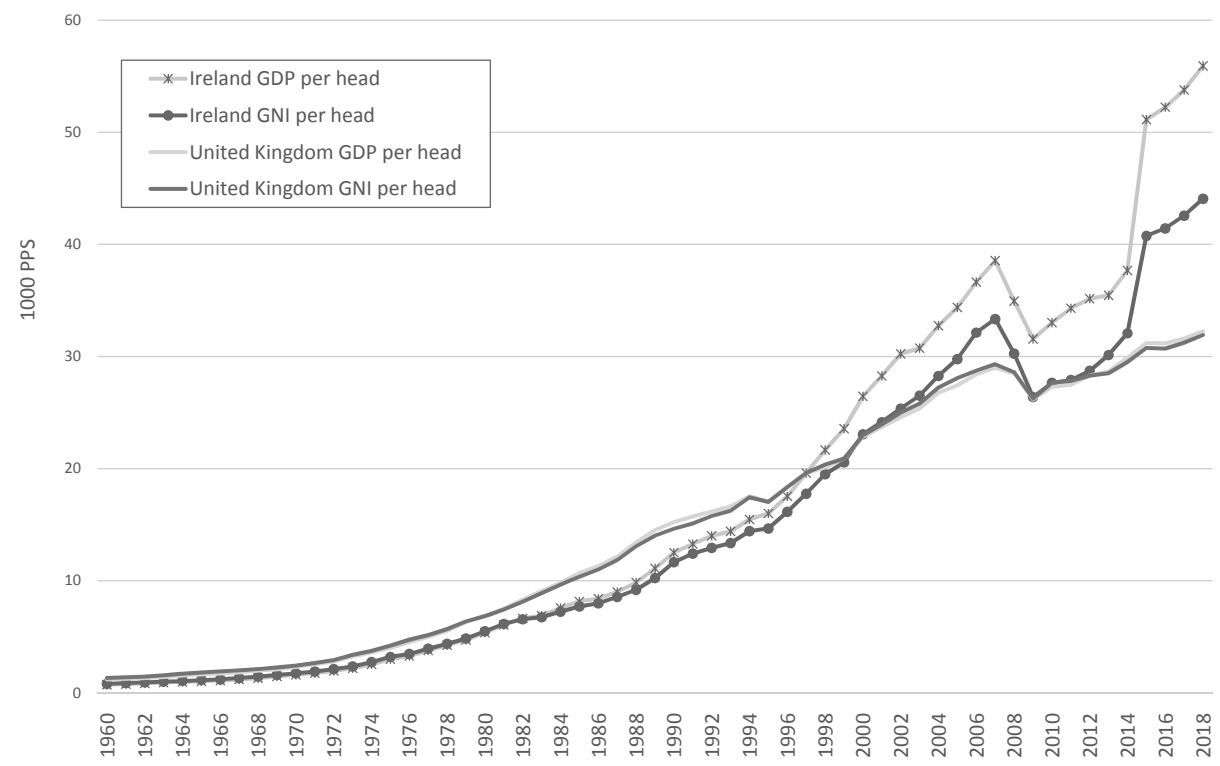

Figure1. GDP and GNI per head in Ireland and the United Kingdom, 1000 PPS, 1960-2018

Source: Author's own production on the basis of the AMECO online database, Table 5.2 and 6.2 http://ec.europa. eu/economy finance/ameco/user/serie/SelectSerie.cfm 
The economic development, measured in GDP per head, resulted in a catching up process by the end of the 1990s (Figure 1). However, this result has to be taken cautiously, as the GDP does not properly indicate the performance of the Irish economy. GDP includes the undistributed profits of the transnational corporations doing business in Ireland that are to be paid to overseas shareholders. Besides, due to the low Irish corporation tax (12.5\%), TNCs reported the revenues of their overseas affiliates in Ireland. For this reason, the GNI or the GNP (the two are practically the same), which exclude the production of foreign-owned companies located in the country, are usually preferred to measure the economic output of Ireland. While GDP and GNI (GNP) are usually more or less equal in most countries, they have increasingly diverged in Ireland since the 1980s. In 2015 and 2016, the Irish GDP was higher by 25-26\% than the Irish GNI. However, in the last decade, problems emerged with this indicator as well, because of the re-registering of companies in Ireland and the tax inversions. Re-registering means that a company relocates its headquarter to Ireland without relocating any real activity to the country (they are also called "redomiciled" companies). Tax inversion takes place when a foreign firm is taken over by a company that is registered in Ireland, again without generating any real employment, production, or purchases of inputs in Ireland. In both cases, the companies are counted as "Irish" and their undistributed profits increase the Irish GNI (GNP), distorting the picture about the strength of the economy (FitzGerald 2013; White 2016).

\section{STATE PLANNING AND SOCIAL PARTNERSHIP}

State planning has a long history and varying degree of success in Ireland. ${ }^{3}$ Its beginnings can be traced back to the early years of public investments. The priority of the first Public Capital Programme (PCP) in 1926 was repairing the damages of the civil war (1921-1925). It was followed by 2- to 6-year programmes with changing goals and compositions. Later, the PCPs were adjusted to the broader national economic plans, of which the first was implemented between 1959 and 1963. As mentioned above, in 1957/1958, a comprehensive study was prepared under the umbrella of the Ministry of Finance, which later formed the basis of the First Programme for Economic Expansion (1959-1963). This programme or plan aimed at the makeover of the economic policy, replacing protectionism and import substitution by trade liberalisation and export orientation. The plan favoured the productive sectors, first of all agriculture, with the goal of lowering tax on profits, deceleration of wage growth, and an increase in productivity. Al-

For more details about state planning in Ireland, see Leddin - Walsh (1995). 
though only a smaller part of the plan's objectives was met, the merit of the First Programme for Economic Expansion was that it made acceptable to the public that the role of the policy is to support economic growth and that an outward looking economic strategy is needed for economic growth.

The Second Programme (1964-1970) built on the assumption that Ireland, together with the United Kingdom, would become members of the EEC in 1964; however, de Gaulle vetoed the British application for membership at the end of 1963. The fate of the Third Programme for Economic, Social Development (19691972) was no better either, because its objectives such as increasing employment proved to be unrealistic, partly in the light of the delayed EEC membership.

These fiascos, then the oil price shock in 1973/1974, and the escalating violence in Northern Ireland set aside state planning ambitions for some years. The belief in visionary economic policy returned only in 1977, with the new Fianna Fail (the Republican Party of Ireland) government that won the elections with the promise of national reconstruction and real security for all members of society. To reach its goals, the government created a new ministry (Department of Economic Planning and Development) that prepared a new plan (National Development 1977-1980). This projected 7\% average annual economic growth based on public sector investments, which could encourage private sector activity. The plan failed because of the second oil price shock in 1979.

In the following years, the fight against the imbalances of the economy was the most important task of government. Plans regarding sectoral structures were not prepared. In 1979, Ireland entered the European Monetary System that required a continuous increase in the competitiveness of the Irish economy. For this, the level of wages and the exchange rate became the most important variables of economic policy. In 1981, the Committee on Costs and Competitiveness was established, with the task of determining the right pace of wage increase, taking into consideration the wages of competitor countries and their exchange rates. In October 1981, the sudden fall of the value of the British pound (GBP) upset the targets planned by the Committee. The substantial depreciation of GBP required more restrictions on Irish wages than had been planned. It became clear that the development of wages could not be dependent upon the hectically changing exchange rates.

Learning from this event, the government prepared a new plan (The Way Forward) that was built upon the projected increase of productivity on the one hand and a moderate wage growth on the other. As, however, the Fianna Fail lost the next general election and its rival party, Fine Gael (the liberal-conservative party) formed a coalition government with the Labour Party, The Way Forward did not even enter into force. 
The new government established a new institution, the National Planning Board, which prepared the Proposal for Plan 1984-1987. This proposal returned to the practice of the First Programme for Economic Expansion (1959-1963) inasmuch as it included sectorial policies. The new national plan (Building on Reality) for 1984-1987 was based on this proposal. It aimed at decreasing the public debt and taxes, lowering of long-term unemployment, and the promotion of privatisation and deregulation. These objectives proved to be too ambitious: the fiscal balance deteriorated, employment failed to increase, and GDP actually fell somewhat in 1985 .

At this moment, the history of state planning arrived at a milestone: after years of unsuccessful planning, the government decided to incorporate social partners into the process. Before this, Ireland did not have an institutionalised and coordinated wage settlement mechanism that would have integrated both trade unions and employers' organisations. Since 1987, however, social partnership became the basis of the strategic planning of governments for the ensuing decades. This idea received a backwind from the EU, which, under Jacques Delors' leadership, began to institutionalise social partnership at the European level. The European social dialogue started in 1985, when the social partners met at the European level for the first time at Val Duchesse (Belgium). In 1986, by the Single European Act, the EU recognised the European social dialogue formally and incorporated into the Treaty of the EC.

Under such circumstances, the Irish Cabinet led by Charles J. Haughey established the institution of Irish social partnership, which went beyond wage settlement mechanism: it was based on the idea of national strategic planning. Having this character, the Irish social partnership has become more like the Germantype "neo-" or "post-corporatism" than the industrial relations of the UK (Regan 2012; Teague - Murphy 2004). This neo- or post-corporatist system has three distinctive features (Teague - Murphy 2004). Firstly, it is broader than the traditional forms of tripartite social partnership that is also applied by the EU on the supranational level (incorporating the representatives of employees, employers, and the government), involving many different civic organisations into the formation of the national development plans and social agreements. Secondly, it represents a move away from representative democracy towards deliberative and participatory democracy inasmuch as it integrates the stakeholders at all levels of decision-making and the implementation of policy measures (Harris et al. 2013). Thirdly, thanks to the participation of the civic organisations at the local level, the Irish model is more decentralised than the traditional tripartite method. However, these institutional features mostly mean potentials only that still have to be exploited. In reality, the local institutions of democracy have remained relatively weak in the first one and a half decade of the post-corporatist social partnership of 
Ireland. The local partnerships "have not led to ordinary people or 'third sector' groups exercising greater control over the exercise of power. As a result, it would be misleading to present them as examples of empowered participatory democracy" (Teague - Murphy 2004: 31). The following years could have brought an improvement in this field, but the 2008 crisis interrupted this development.

Nevertheless, this model of partnership has functioned to the satisfaction of all parties for two decades. The partners discussed the socio-economic developmental path of the country tri-annually and agreed on wage increases for that period. The government offered tax reductions that enabled real labour incomes to grow without causing a major nominal increase in labour compensation, which was beneficial to the enterprises. Trade unions proved to be successful representatives of labour interests, without being forced to fight for wage increases (the trade unions accepted that they would refrain from strikes on issues that are affected by the agreement). The stable, predictable wage development - a continuous "internal devaluation" - together with a low taxation of profit has made the Irish economy an even more attractive destination for foreign investments than before and enabled it to adjust to the requirements of the European Monetary System.

This system of social partnership has been embedded into the institutional system of the "flexible" and "networked" developmental state and has provided a means of adjustment for the capital to the increased competition on the global market. Together with the advantageous global economic environment (IT boom in the US in the 1990s, the credit boom, and the euro zone membership in the 2000s), this helped to increase employment, which, given the weak social policy in Ireland, is the basic tool for alleviating poverty. Yet, the critics of the system argue that it helped to depress the wage per profit ratio and could not mitigate the problem of increasing social inequalities (Allen 2000; Hardiman 2005).

Between 1987 and 2008, seven social pacts were concluded. In 2009, due to the global crisis that broke out in the last year of the seventh agreement, the high exchequer deficit, the growing unemployment (from $4 \%$ to $12 \%$ in two years), and the income cuts in the public sector, the system of social partnership practically collapsed and the practice of national pay agreements was replaced by local wage bargaining (Glassner - Keune 2010). In March 2010, public service trade unions and the government negotiated a three-year pay freeze (Glassner 2010). Strategic planning was replaced by crisis management in the form of a rigorous fiscal adjustment programme under the supervision of the "troika" (the European Commission/Eurogroup, the European Central Bank, and the IMF).

In January 2015, the Irish government expressed its intention to reopen a dialogue with the trade unions concerning a joint wage rise and tax relief package for employees (McEnroe et al. 2015). Still, the above-described social partnership has not been revived yet. 


\section{THE ROLE OF STATE OWNERSHIP}

Historically, the first public enterprises were established in the commercial sector in 1927 (Dairy Disposal Company, Agricultural Credit Corporation, Electricity Supply Board). Between the mid-1930s and the end of the 1950s, numerous state companies were founded (Irish Sugar Company, Industrial Credit Corporation, Aer Lingus in 1936, Aer Rianta in 1937, Ceimici Teo in 1938, Coras Iompair Éireann in 1944, Irish Steel, Bord na Mona in 1946) with the aim of promoting self-sufficiency in sectors such as food, banking, air transport, and steel and peat production. With the adoption of the outward-looking economic strategy in the late 1950s, the focus of the industrial policy also changed. In the next decades, SOEs were established in order to develop infrastructure such as broadcasting (RTE), gas distribution (Bord Gáis), shipping (British and Irish Line), telecommunication (Telecom Éireann), and postal service (An Post). There were only a few industrial SOEs established (Forfás 2010: 17-18).

In 2016, the combined share of employees in public administration and defence, and the compulsory social security in employment was $5.1 \%$, the second lowest after Finland among the EU-28. The weight of state ownership was also one of the smallest in international comparison, even though its importance for the country's economic development is hardly negligible. At the same time, all SOEs are open to competition for market share and may compete with each other as well.

In July 2010, Forfás, the national policy advisory board for enterprise, trade, science, technology, and innovation, published a study about the role of SOEs in Ireland. ${ }^{4}$ According to this document, SOEs employed over 41 thousand people or $2.1 \%$ of total employment. The turnover of SOEs was equal to $5.8 \%$ of GDP and the book value of their non-current assets reached $€ 17.44$ billion or $9.5 \%$ of GDP. The net debt and pension liabilities of these companies together reached $€ 8.3$ billion (Forfás 2010: 3). Note, however, that three decades earlier, the role of SOEs was even more important. In 1980, they employed nearly 90 thousand people. This decline was due partly to privatisations and partly to "rationalisation" processes in the remaining SOEs (Forfás 2010: 12).

Today, SOEs provide infrastructure and services that are essential for the competitiveness of the economy: energy, water and waste water (supplied by local authorities), waste management, road, rail, air, and sea transport services, and information networks (Broadband and Next Generation). They also promote economic development by providing a developed and relatively low-cost investment

4 Since then, Forfás has been integrated into the Department of Jobs, Enterprise and Innovation, that has not put out any similar publications since then. 
climate. Although SOEs enjoyed state subsidies in the past, especially in the first years of the recent crisis, the bulk of their revenues came from their own economic activity: fees for services and goods provided to customers (Forfás 2010).

\section{CYCLES OF NATIONALISATION AND PRIVATISATION}

Nationalisation and privatisation cycles have existed since the early years of capitalism all over the world. These changes in the structure of property have usually come in waves affecting several countries (Chang et al. 2009; Siegmund 1996; Chua 1995). For example, a wave of nationalisation occurred after World War 2 in both Eastern and Western Europe, while the crisis of the 1970s was followed by two decades of privatisation in the 1980s and 1990s. Smaller waves took place in many countries such as France, where the Mitterrand administration first nationalised a series of large banks and industrial firms in 1982, but then turned back to privatisation a few years later (Siegmund 1996). Empirical studies have also proven that nationalisation-privatisation cycles tend to affect natural resource and utility sectors more often than other sectors, particularly if commodity prices are

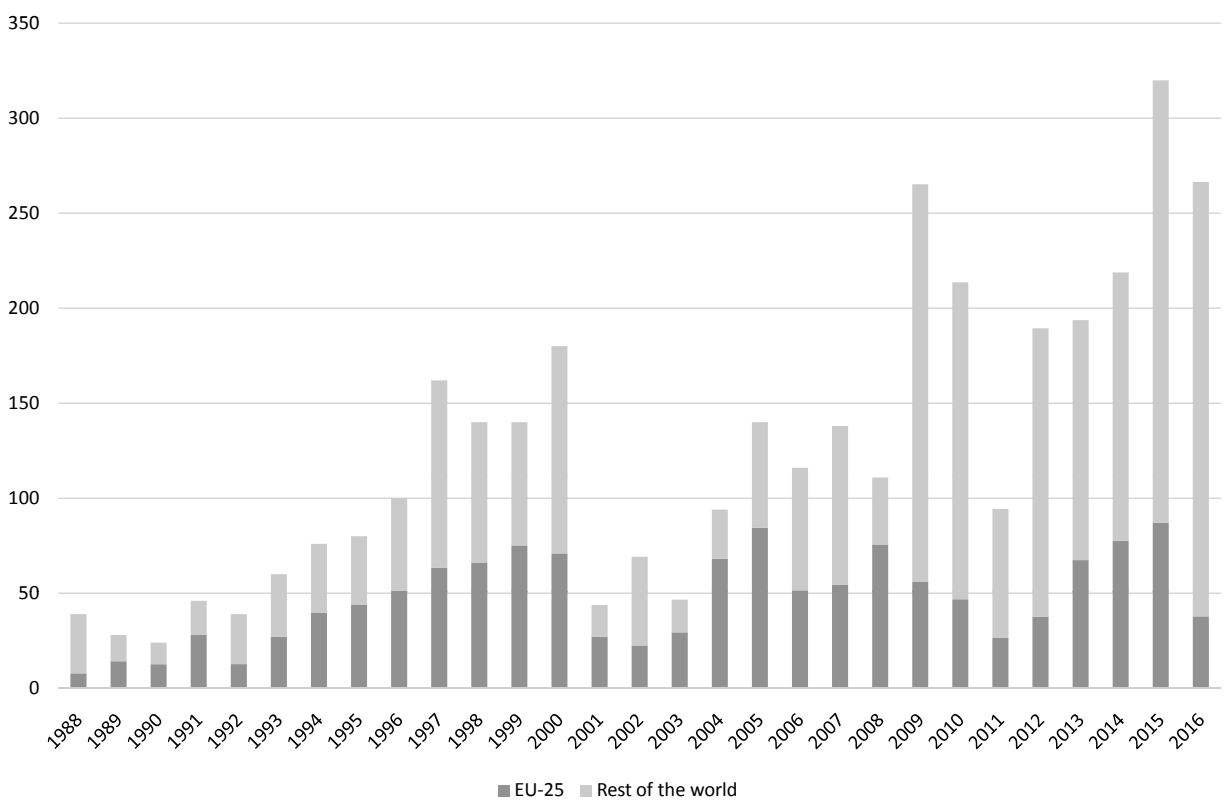

Figure 2. Revenues from privatisations, EU-25 and rest of the world, 1988-2016, USD billions Source: The PB Report 2015/2016, Table 1. 
high. Besides, nationalisation is also likely to serve mitigating inequality and poverty through the expropriation of the revenue-generating companies in the utility and natural resource sectors (Chang et al. 2009). ${ }^{5}$

There have been three waves of privatisation in Europe since 1990. Each has been larger than its predecessor and the fallbacks after the peak years have been smaller and smaller as well (Figure 2). Due to the 2008 crisis, a new wave of nationalisations, mostly of banks, occurred that was followed by a tide of (re)privatisation. Ireland has more or less followed these privatisation-nationalisation waves.

\subsection{Privatisations before the 2008 crisis}

With the worldwide awakening of neoliberalism, successive Irish governments too began to sell public companies, similarly to other countries. Between 1991 and 2008, the state withdrew from a number of service and manufacturing sectors (shipping, telecommunication, sugar, steel) and realised proceeds of an estimated $\$ 8.9$ billion (Table 1). The most important privatisations are described below.

The Irish Sugar Manufacturing Company Ltd. was established as a private company in 1922 and was nationalised because of the Great Depression (19291933) by the Sugar Manufacture Act in 1933. At the time, the government's goal was to promote self-sufficiency in sugar production. The company was privatised by the Sugar Act in 1991 through the establishment of a new state-owned company named Greencore Group plc, 55\% of which was listed on the Irish Stock Exchange in the year of the start-up. The remaining state shares were privatised in 1992 and $1993 .^{6}$

The British and Irish Steam Packet Company (B\&I), a ferry, was established by English capital in Dublin in 1836. In 1965, the government took it over, modernised it, and increased its scope of activity. In 1981, the financial position of the company deteriorated and could not be repaired through a decade. In 1992, B\&I was privatised, taken over by Irish Continental Group (an Irish-Scandinavian joint venture that was formed in 1972).

Bord Telecom Éireann (the Irish Telecommunications Board) started its operation as a state-owned company founded by the Postal and Telecommunications

5 The poverty-alleviating function of nationalisations is particularly important for the developing countries, where strengthening market forces after privatisations may severely increase inequalities and aggravate social divisions, which often take the form of violent ethnic conflicts (Chua 1995).

6 Greencore Group homepage archive: http://archive.is/YFk4g 
Table 1. Privatisations in Ireland 1991-2013

\begin{tabular}{|c|c|c|c|c|}
\hline Year & Company Name & Sector & $\begin{array}{l}\% \text { for } \\
\text { Sale }\end{array}$ & $\begin{array}{l}\text { Value of } \\
\text { Transaction } \\
\text { in US\$ } \\
\text { million }\end{array}$ \\
\hline 1991 & Verolme Dockyard & Transportation Industry & 100.0 & 1.804 \\
\hline 1991 & Greencore & Manufacturing & 54.6 & 142.500 \\
\hline 1991 & Irish Life PLC & Finance \& Real Estate Industry & 46.0 & 117.000 \\
\hline 1991 & Irish Life PLC & Finance \& Real Estate Industry & 5.0 & 35.093 \\
\hline 1992 & B\&I Lines & Transportation Industry & 100.0 & 14.442 \\
\hline 1992 & Greencore & Manufacturing & 15.0 & 52.536 \\
\hline 1992 & Abbey Life & Finance \& Real Estate Industry & 100.0 & 35.025 \\
\hline 1993 & Irish Life PLC & Finance \& Real Estate Industry & NA & 160.418 \\
\hline 1993 & Greencore & Manufacturing & 30.4 & 107.457 \\
\hline 1995 & Irish Life PLC & Finance \& Real Estate Industry & 15.3 & 160.500 \\
\hline 1996 & Irish Steel & Manufacturing & 100.0 & 34.683 \\
\hline 1996 & Telecom Eireann & Telecommunications & 20.0 & 289.872 \\
\hline 1999 & Telecom Eireann & Telecommunications & 15.0 & 278.834 \\
\hline 1999 & Telecom Eireann & Telecommunications & 50.0 & 3.529 .800 \\
\hline 1999 & Telecom Eireann & Telecommunications & 15.0 & 502.128 \\
\hline 1999 & Cablelink Ltd & Telecommunications & 100.0 & 724.456 \\
\hline 2001 & TSB Bank & Finance \& Real Estate Industry & 100.0 & 382.482 \\
\hline 2001 & $\begin{array}{l}\text { Irish National Petroleum } \\
\text { Corp }\end{array}$ & Petroleum Industry & 100.0 & 100.002 \\
\hline 2002 & ACC Bank PLC & Finance \& Real Estate Industry & 100.0 & 146.605 \\
\hline 2004 & Opodo (AER Lingus, 8 Oths) & Transportation Industry & 38.0 & 75.279 \\
\hline 2005 & $\begin{array}{l}\text { PostTS Spain (UK \& Spain } \\
\text { divisions) }\end{array}$ & Finance \& Real Estate Industry & 100.0 & 113.712 \\
\hline 2006 & $\begin{array}{l}\text { Great Southern Hotels Ltd- } \\
\text { Hotels (7) }\end{array}$ & Services Industry & 100.0 & 338.433 \\
\hline 2006 & Aer Lingus & Transportation Industry & 60.0 & 818.100 \\
\hline 2008 & $\begin{array}{l}\text { Electricity Supply Board } \\
\text { (ESB) }\end{array}$ & Utilities & 20.0 & 706.769 \\
\hline 2011 & Artizan Shopping Centre & Finance \& Real Estate Industry & 100.0 & 7.964 \\
\hline 2011 & Bank of Ireland & Finance \& Real Estate Industry & 21.0 & 1.558 .100 \\
\hline 2011 & $\begin{array}{l}\text { NAMA Properties - assets } \\
\text { sales }\end{array}$ & Finance \& Real Estate Industry & 100.0 & 5.247 .060 \\
\hline 2011 & Maybourne Hotel Group & Services Industry & 36.2 & 76.108 \\
\hline 2012 & Irish Life PLC & Finance \& Real Estate Industry & 100.0 & 1.710 .900 \\
\hline 2012 & RBS Aviation Capital & Finance \& Real Estate Industry & 100.0 & 7.520 .580 \\
\hline 2013 & Irish Life Group Ltd & Finance \& Real Estate Industry & 100.0 & 1.737 .610 \\
\hline 1991-2008 & & & & 8.867 .930 \\
\hline 2011-2013 & & & & 17.858 .322 \\
\hline 1991-2013 & & & & 26.726 .252 \\
\hline
\end{tabular}

Source: Privatization Barometer Online http://www.privatizationbarometer.com/database.php 
Services Act in 1983. The scope of its services was broadened throughout the years. The company had 8 divisions (mobile phone, videotext systems, the internet, data network, etc.) before its privatisation in 1999. Next year, the company was split into two businesses, one of which (the mobile service) was sold to Vodafone in 2001.

The Agricultural Credit Corporation (ACC) was founded by the state in 1927 as a commercial bank focusing on agriculture and small- and medium-size enterprises (Farkas 1999). In 2002, it was sold to Rabobank, a Dutch co-operative bank, for $£ 150$ million. After 2007, ACC Bank reported losses, gave up its banking license, its local offices were closed, its employees were dismissed, and the management of loan facilities was centralised. The parent company, Rabobank, could manage the problem with these measures and no nationalisation was needed for the time being, although the trade unions, trying to protect jobs, asked the government to take ACC Bank back into state ownership in 2013 (RTÉ 2013).

The Industrial Credit Company (ICC) was modelled on ACC. It was launched in 1933 as an investment bank to support economic activity. In 2001, the state sold ICC to the Bank of Scotland (BoS). BoS was exposed to the property market in the credit boom of the 2000s, became indebted, and had to finish its activity in Ireland in 2010 (NAMA Wine Lake 2013). Aer Lingus, the national airline company was established under the Air Navigation and Transport Act in 1937. The share of the state remained decisive for decades, being equal to $85 \%$ in 2006 . With increasing competition in the aviation market in the 2000s, difficulties emerged. In 2006, the government decided to float the company on the stock exchange. The state maintained $28 \%$ shareholding, which later fell to $25 \%$. Even this packet was sold to IAG, a multinational airline holding company, in May 2015 (Kelly Taylor 2015).

\subsection{Privatisations due to the 2008 crisis}

The consequences of the 2008 crisis - the soaring fiscal deficit and public indebtedness caused by the bailouts - forced the government to increase its revenues by selling out its property. Privatisations also occurred after the nationalisation of the troubled banks that we will discuss later.

Outside the banking sector, the most important privatisation affected the energy and water supply sector. In March 2014, the retail arm of the state-owned Bord Gáis Éireann, the country's biggest electricity and gas provider, was sold to the British multinational, Centrica Plc, for $€ 1.1$ billion (Reuters 2014). In 2013, the government set up a company, Irish Water, to manage the water supply and to charge for water usage. This company was established as a subsidiary of Bord Gáis Éireann that changed its name to Ervia in 2014. These transactions indicate 
that following the privatisation of electricity and gas, water is also progressing towards privatisation. However, water has turned out to be a very sensitive issue for the population.

For decades, Ireland had financed its water supply through general taxes (other European countries levy direct fees for water). However, from January 1, 2014, Irish Water took over responsibility for public water and wastewater services from local governments and began to bill for water, while the government did not reduce residents' general taxes. Thus, the new water charge effectively meant double taxation on water for a population that was already hit hard by fiscal retrenchment in the social sphere. ${ }^{7}$ The government's decision to set up a semi-state company to charge for water usage outraged people, especially because the economy performed very well at the time (in 2014, GDP grew by $5.2 \%$, and by even more in 2015). The water charge would have been a flat fee of $€ 160-260$ per year until December 31,2018, but people feared, from experiences of other countries' water privatisation (e.g. Cochabamba, Bolivia in 2000), that it would increase later. A social resistance unfolded in the form of a boycott of water charges. According to estimations, $57 \%$ of the population refused to pay the water bill in the summer of 2015 (TheJournal.ie 2015a). Due to the social resistance, the government suspended the water charges until April 1, 2017 (Bardon 2017) and on April 13, the Parliament effectively abolished it. However, the story does not end here: the government still intends to charge for excessive water use (meaning that water consumption would be metered and that those whose consumption is more than $170 \%$ of the average daily amount would be charged). This intent is seen by many as an effort to maintain the possibility of general water charges and the privatisation of water (Ward 2017), and thus the struggle between the government and the opponents of water charges was still ongoing at the time of writing this study.

Rail represents another problematic public service. Rail transport is provided almost exclusively by Irish Rail. In 2015, the government came under pressure from the EU to offer it for privatisation. This time, it was the government that resisted. The Irish government is not the only one in this respect: other smaller EU members (e.g. Bulgaria, Estonia, and Luxemburg), which were also advised to privatise their rail, were also reluctant to follow this advice (The Journal. ie 2015b). Although the government had to write off Irish Rail's $€ 150$ million losses during the past seven years, Ireland will not be privatising its domestic

7 For example, 382,000 people were on waiting lists for a hospital outpatient appointment in January 2015, 55,733 had been waiting for over 12 months (Cullen 2015). The Department of the Environment reduced the funding of homelessness service at a time when homelessness increased and rents were on the rise in Dublin (Holland 2015). 
rail "under any circumstances", as the Minister for Transport declared in September 2015 (O'Halloran 2015a). The situation does not seem to have changed since then.

\subsection{Nationalisations due to the 2008 crisis}

In the course of the crisis management, the state acquired substantial equity positions in distressed banks. Initially, the increase of state ownership in the financial sector was planned to be temporary.

Between 2008 and 2013, the government spent money equal to $37.3 \%$ of GDP of 2013 for the bailout of banks, by far the highest ratio in the EU (Milliken 2015). Only less than a third of that money was used to buy assets that could potentially generate a return. The remaining amount went to bank recapitalisations and financing toxic assets (25.6\% of GDP), which meant a loss for the taxpayers (Maurer - Grussenmeyer 2015: 19). These figures do not include the sums that the government had to spend because of the higher unemployment and poverty rates, slower economic growth, and other consequences of the crisis.

Right in time for the first signs of the financial crisis in early October 2008, the government provided a guarantee for all bank deposits that were equal to $€ 440$ billion. A few months later, the state purchased Anglo Irish Bank, one of the biggest banks of the country, for $€ 7$ billion and recapitalised two other banks (Bank of Ireland and Allied Irish Bank) by acquiring a holding in them for $€ 7$ billion (Moya 2009). This was, however, the overture only.

In May 2009, the government established the National Asset Management Agency (NAMA), a public "bad bank", under the aegis of the National Treasury Management Agency. NAMA offered to buy the non-performing loans from the lenders with a discount. The total par value of the non-performing property-related loans that troubled banks sold to NAMA reached $€ 74$ billion, about $44 \%$ of the Irish GDP. In 2010, NAMA bought these loans at a discount of 58\% that cost close to $€ 31.8$ billion ( $€ 30.2$ billion senior bonds and $€ 1.6$ billion subordinated bonds). NAMA was asked to repay the senior debt by $2020 .{ }^{8}$ By the end of 2016 , NAMA had almost reached this goal thanks to its successful business activities such as, for example, its cash-generating activities (rental fees), assets sales, and residential program. In the framework of the latter, NAMA funded the construc-

Whereas the senior bonds must be redeemed, the subordinated bonds, known also as junior bonds, must be repaid only if NAMA beats a target of repaying all the senior debt by 2020 (Brennan 2014). 
tion of almost 2800 new residential units up to late 2015 and has planned to build 10,100 units more in the ensuing years (NAMA 2016).

\section{Bailout of banks}

As the Irish property market collapsed, Anglo Irish Bank became insolvent and needed financial support. At the end of 2008 , the state offered $€ 1.5$ billion for $75 \%$ of the bank's shares, but later decided to take it over entirely. The costs of purchase have proved to be minor relative to the huge amount of money that became necessary later to save this bank (RTÉ 2011; The Telegraph 2010).

Allied Irish Banks (AIB) was partly nationalised in December 2010, but later the share of the state grew to $99.8 \%$. The bailout of AIB required $€ 21$ billion from the government.

In 2010, the Irish Nationwide Building Society (INBS) was also nationalised. Together with the Anglo Irish Bank, this was undertaken by the Irish Bank Resolution Corporation (IBRC), which was formed on July 1, 2011, for this purpose. The liabilities of the two banks (Anglo and INBS) incorporated into IBRC amounted to $€ 31$ billion ( $€ 25.3$ billion for Anglo and $€ 5.3$ billion for INBS; Carswell 2012). ${ }^{9}$ The government took over these liabilities in the form of issuing so-called promissory notes, known also as IOUs ("I owe you"), to the lenders. Out of these $€ 31$ billion notes, $€ 3.1$ billion was to be changed for hard cash to the creditors every year until 2021. In the meantime, interests would have to be paid as well. This meant that the government would have to inject $€ 47.4$ billion into IBRC over 21 years, comprising $€ 30.6$ billion in capital and $€ 16.8$ billion in interest (Carswell 2012). The amount of interest would burden the public budget for a decade and would require tax rises or spending cuts year by year. This would likely result in continuous public anger. For this reason, the government was interested in reducing the burden of the promissory note payments. Besides, the nature of financing through IOU was also problematic, as it contradicted the Maastricht rules according to which national governments (national banks) are not allowed to print money. Given these problems, after months of secret preparations, a decision was made through the night of February 6 to 7, 2013, on the liquidation of IBRC (TheJournal.ie 2013). The goal of the decision was to find a better and cheaper way for financing the liabilities than the promissory notes (IOUs). NAMA gave $€ 12.9$ billion to IBRC in the form of government guaranteed bonds, the interest of which is lower than that of the promissory notes. IBRC

9 According to other sources, Anglo Irish Bank and Irish Nationwide together got $€ 34.7$ billion in 2009 and 2010 via share capital and the promissory notes (Hancock 2014). 
managed to sell its assets worth of $€ 21$ billion until April 2014 and repaid the $€ 12.9$ billion to NAMA (Hancock 2014).

Due to the liquidation of IBRC, NAMA's balance sheet improved considerably by the end of 2015 (Table 2). The sale of the mortgage books of IBRC meant that the loans went into the pocket of non-regulated distressed securities, or "vulture funds", that are not advantageous for debtors (TheJournal.ie 2014).

\subsection{Reprivatisation after nationalisation}

Reprivatisation became possible when investors' confidence was restored. This was due firstly to NAMA's policy and, later, to the successful completion of the structural adjustment programme prescribed by the institutional lenders (the euro zone and the IMF).

In the first years of its operation, NAMA aimed at reconstructing the activity on the property market that was sluggish from 2009 to 2012, with little or no investment activity. As NAMA's chairman, Frank Daly explained the sale of $€ 1$ billion Irish assets at low prices, "NAMA's first task was to try to stabilise the situation. We re-kindled activity by releasing transactions into the market at a rate that the market could absorb" (NAMA 2016: 7). For this transaction, NAMA was accused of engaging in "fire sales" of assets. ${ }^{10}$

Within the framework of the Economic Adjustment Programme (signed in December 2010), the EU and the IMF provided financial assistance of $€ 67.5$ billion to Ireland. The government used a further $€ 17.5$ billion from the Treasury and the National Pension Reserve Fund to rescue the banks. The Economic Adjustment Programme contained the austerity measures needed to improve the budgetary balance and repay the debt. As the government successfully completed the program by 2013, investors' confidence was restored for the sovereign and the banks, and NAMA could go ahead with reprivatisation deals.

The earliest reprivatisation transaction of the Irish government in the course of crisis management took place in connection with an insurance company in 2013. In the course of its history, Irish Life Assurance (Irish Life Group Ltd) was purchased and resold by the Irish state twice. Although the company was never fully owned by the state between 1947 and 1991, the government had a 90.25\% stake in it. In 1991, the state shares were released on the market. Irish Life was one of the founders of Irish Life and Permanent Plc., a personal financial services

10 For example, NAMA "sold the Forum building in the IFSC [in Dublin] for $€ 28$ million in 2012 to US private equity firm Atlas Capital, which sold it on less than two years later for $€ 37.8$ million" (O'Halloran 2015b). 
provider company. The originally state-owned TSB (Trustee Savings Bank) was sold to the Irish Life and Permanent in 2001. Due to the 2008 crisis, however, Irish Life and Permanent required additional regulatory capital of $€ 4.0$ billion because of the toxic assets of TSB. $€ 2.7$ billion was transferred in July 2011, and the remaining $€ 1.3$ billion derived from the nationalisation of the then still profitable Irish Life Group Ltd. The state purchased Irish Life from Irish Life and Permanent in June 2012 (ILGL, 2012: 4). After this, the company was rapidly reprivatised: in July 2013, it was sold to the Canadian Great-West Lifeco at the purchase price, i.e. for $€ 1.3$ billion (GWL 2013).

Since 2014, after the completion of the adjustment programme, the Irish state has accelerated the sale of its loan and real estate portfolio that it took over from troubled financial institutions years earlier. NAMA took advantage of the increasing demand for real estates after 2013. It managed to realise $€ 7.8$ billion from sales of non-performing loans, property, and other assets in 2014 and $€ 8.5$ billion in 2015. In the same year, the Agency could raise its profit considerably, to $€ 1.8$ billion, up from $€ 648$ million in 2014. However, a significant part of NAMA's 2015 profit arose due to once-off factors, which are unlikely to be repeated (for the key financial data for 2014-2015, see Tables 2 and 3). The total sales of NAMA since its establishment until the end of 2015 reached $€ 24.6$ billion. By that time, other incomes (mainly rental receipts from properties controlled by debtors and receivers) amounted to $€ 5.5$ billion, meaning that the total cash generated since 2010 has reached $€ 32.7$ billion. Another $€ 1.3$ billion has been generated in the first three months of 2016. The public "bad bank" has planned to redeem at least $80 \%$ ( $€ 24$ billion) of senior debt in 2016 , two years earlier than originally planned (NAMA 2016).

Table 2. NAMA Summary balance sheet, as of December 31, 2015, 2014, million EUR

\begin{tabular}{l|r|r}
\hline & \multicolumn{1}{|c|}{2015} & \multicolumn{1}{c}{2014} \\
\hline Assets & & \\
\hline Cash and cash equivalents and liquid assets & 3,402 & 1,849 \\
\hline Loans and receivables (net of impairment) & 7,816 & 13,360 \\
\hline Other assets & 348 & 363 \\
\hline Total assets & 11,566 & 15,572 \\
\hline Liabilities and reserves & & \\
\hline Senior debt securities in issue & 8,090 & 13,590 \\
\hline Other liabilities & 270 & 744 \\
\hline Total liabilities & 8,360 & 14,334 \\
\hline Total equity and reserves & 3,206 & 1,238 \\
\hline Total equity, reserves and liabilities & 11,566 & 15,572 \\
\hline
\end{tabular}

Source: NAMA (2016: 68). 
Table 3. NAMA Consolidated statement of financial position, as of December 31, 2015, 2014 million EUR

\begin{tabular}{l|r|r}
\hline & 2015 & 2014 \\
\hline Interest and fee income & 614 & 955 \\
\hline Interest expense & -221 & -313 \\
\hline Net interest income & 393 & 642 \\
\hline $\begin{array}{l}\text { Net profit on disposal of loans, property assets; and surplus } \\
\text { income }\end{array}$ & 1,587 & 317 \\
\hline Foreign exchange & -14 & -22 \\
\hline Derivatives & -134 & -159 \\
\hline Administration and other income / (expenses) & -63 & -99 \\
\hline Operating profit before impairment & 1,769 & 680 \\
\hline Impairment charge & 86 & -170 \\
\hline Profit for the year before tax & 1,854 & 510 \\
\hline Tax charge & -28 & -52 \\
\hline Profit for the year & 1,826 & 458 \\
\hline
\end{tabular}

Source: NAMA (2016: 68).

All in all, NAMA has been performing well. It has bought $€ 74$ billion risky loans from troubled financial institutions at a discount price for government bonds worth $€ 32$ billion and this amount has already returned to the Agency in terms of cash generation. However, as mentioned earlier, this $€ 32$ billion was not the only cost in relation to the banking crisis. The bailout of banks swallowed altogether $€ 64$ billion of public money between 2008 and 2014 (Boland 2014). In 2016, Ireland's national debt was still €201 billion (€47.1 billion in 2007) and reached $75.4 \%$ of GDP $(23.9 \%$ in 2007$)$.

In May 2015, the Department of Finance valued the state's holdings in Allied Irish Bank, Bank of Ireland, and Irish Life \& Permanent (TSB) at about $€ 16.4$ billion. According to Minister for Finance Michael Noonan, the state can expect to get back all the money it put into the financial institutions. However, the $€ 35$ billion that was used to support the two banks of IBRC (Anglo and INBS) will not be recouped (Hancock 2015).

In 2015, the Economic and Social Research Institute (ESRI) urged the speedup of the privatisation of state ownership in banks in order to boost competition in the financial and mortgage sector that would decrease the costs of borrowing and promote the growth of consumption and investments. According to Professor Kieran McQuinn, privatisation would have positive effects on the real economy and has to be accelerated for this reason, even if the state had to accept some loss on its bank-related investments (Beesley 2015). 


\section{DAMAGING THE STATE}

The political sphere is relatively clean in Ireland in international comparison. The country has usually been among the best 20 nations in the ranking lists of Transparency International. However, the crisis and its management did not happen without scandals, which indicated that the role of "the lender of last resort" offers a good opportunity for market actors to misbehave.

As it turned out, the top executives of Anglo Irish Bank lied to the government about the true financial position of AIB to get billions of euros in the form of state assistance. In September 2008, the Irish government offered $€ 7$ billion to bail out Anglo. The bank's chief executives accepted it without telling the government what they knew - that this would not be enough by far. They thought that if they told the truth, the government might find the price of the bailout too high and would be unwilling to give money. They also knew that there was no chance of repaying the loans. The Irish Independent summarised the essence of a tape recording of two senior managers of Anglo (John Bowe and Peter Fitzgerald) were laughing and joking about their "successful" tactics against the state:

Mr Bowe is asked by Mr Fitzgerald how they had come up with the figure of $€ 7 \mathrm{bn}$. $\mathrm{He}$ laughs as he is taped saying: "Just, as Drummer (then-CEO David Drumm) would say, 'picked it out of my arse'."

He also says: "If they (Central Bank) saw the enormity of it up front, they might decide they have a choice. You know what I mean?

"They might say the cost to the taxpayer is too high ... if it doesn't look too big at the outset ... if it looks big, big enough to be important, but not too big that it kind of spoils everything, then, then I think you have a chance. So I think it can creep up."

Mr Fitzgerald, the Director of Retail Banking, is heard saying: "Yeah. They've got skin in the game and that is the key."

Mr Bowe's comments in the audio recording reveal that Anglo's strategy was to lure the State in, leaving taxpayers with no choice but to continue to provide loans to "support their money" (Williams 2013).

In 2008, another major scandal was revealed, once again in connection with the Anglo Irish Bank. Between 2000 and 2008, Sean Fitzpatrick, Chairman of the bank, extended huge loans to himself from the bank's funds. These loans were hidden from the regulators by transferring the money temporarily to another bank during the time of year audits. The 2008 crisis unfolded the fraud. Fitzpatrick was not the only director who committed "irregularities" that injured the bank's financial stability. He had personally hidden $€ 87$ million in loans, and several more directors had hidden a further $€ 150$ million (Chu 2014). 


\section{CONCLUSION}

After the 1950s, Ireland gradually became an export-oriented, free-market, and FDI-attracting economy with a moderate social welfare system and small state intervention in the economy. By the 2000s, the direct economic role of public ownership was limited and the activity of SOEs concentrated in the key infrastructural sectors. The model of the Irish "networked developmental state" has not changed basically since then, but has undergone some alterations inasmuch as the direct role of state became somewhat smaller by the end of the crisis. This shrinking of the state's role occurred through the cycles of nationalisation and privatisation. As the country is deeply integrated into the global economy, these cycles fitted into the global nationalisation-privatisation waves, following the needs of the global reproduction of capital.

The 2008 crisis brought a merely temporary increase in the state intervention. Although the Irish state poured a lot of money into the private banking sphere and nationalised banks, it did not intend to retain its ownership in the long run. The government has been seeking the possibilities of fast reprivatisation and this behaviour is likely to continue in the coming years until all the shares that had been purchased with the aim to save the banks will be sold.

Thus, contrary to expectations, the crisis eventually strengthened the liberalisation course: the huge hole in the budget and the high public debt that were the results of the crisis management forced the government to find extra revenues through the privatisation of its traditional service companies as well. In this way, the state's role in infrastructure decreased (gas and electricity privatisation) and will probably decrease further (water and rail). At the same time, the social welfare system has been curtailed instead of improved - although the improvement would have been timely and had been urged by experts of the social partners well before the 2008 crisis (NESC 2005). The evolution of "the developmental welfare state" became less likely in the course of and as a result of crisis management.

We can conclude that although the cycles of the capitalist reproduction need state intervention from time to time, in the case of a country that is deeply integrated into the global economy, the role of state is limited to the "lender of last resort", the maintenance of the business climate beneficial for the profit generation. Another lesson is that the state can manage certain bad assets of the private sector in a way that yields a profit to the public. There are other costs of the crisis management, however, which are to be paid by the people and result in a decrease of state ownership and a shrinking of the welfare systems. 


\section{REFERENCES}

Adshead, M. - Millar, M (2003): Ireland as Catholic Corporatist State: A Historical Institutional Analysis of Healthcare in Ireland. Department of Politics and Public Administration, University of Limerick, Ireland. Paper, No. 5. http://www.ul.ie/ppa/content/files/258567748.pdf

Allen, K. (2000): The Celtic Tiger: The Myth of Social Partnership. Manchester: Manchester University Press.

Bardon, S. (2017): Water Charges Q\&A: Will I Get My Money Back? The Irish Times, February 28. http://www.irishtimes.com/news/politics/water-charges-q-a-will-i-get-my-money-back1.2992810

Barry, F. (2003): Irish Economic Development over Three Decades of EU Membership. Finance a úvûr - Czech Journal of Economics and Finance, 53(9-10): 394-412.

Beesley, A. (2015): ESRI Urges Faster Sale of State-Owned Bank. The Irish Times, June 10. http:// www.irishtimes.com/business/economy/esri-urges-faster-sale-of-state-owned-banks-1.2243449

Bielenberg, A. - Ryan, R. (2013): An Economic History of Ireland since Independence. New York: Routledge.

Boland, V. (2014): Report Highlights High Cost of Irish Bank Bailout. Financial Times, March 20, http://www.ft.com/intl/cms/s/0/79e59f5c-b050-11e3-8058-00144feab7de.html\#axzz3n2FqAs2n

Boyle, N. (2005): FÁS and Active Labour Market Policy 1985-2004. Studies in Public Policy, No. 17. The Policy Institute.

Brennan, J. (2014): Boost for Banks as NAMA to Make Payments on Junior Debt. Irish Independent, February 25, http://www.independent.ie/business/irish/boost-for-banks-as-nama-to-makepayments-on-junior-debt-30037838.html

Chang, R - Hevia, C. - Loayza, N. (2009): Privatization and Nationalization Cycles. Washington, D.C.: World Bank, July.

Carswell, S. (2012): Breaking the Promissory Notes to Ease Burden on State. The Irish Times, January 30, http://www.irishtimes.com/business/financial-services/breaking-the-promissorynotes-to-ease-burden-on-state-1.454093

Central Statistical Office of Ireland, http://www.cso.ie/en/statistics/nationalaccounts/

Chu, W. (2014): The Fall of Anglo Irish Bank. Sevenpillars Institute December 11th, http://sevenpillarsinstitute.org/case-studies/fall-anglo-irish-bank

Chua, A. (1995): The Privatization-Nationalization Cycle: The Link between Markets and Ethnicity in Developing Countries. Columbia Law Review, March, 95(2): 223-303.

Considine, M. - Dukelow, F. (2010): Introduction, Boom to Bust: Irish Social Policy in Challenging Times. Irish Journal of Public Policy, 2 http://publish.ucc.ie/ijpp/2010/01/considinedukelow/00/ en

Crafts, N. (2008): The Celtic Tiger in Historical and International Perspective. Warwick Economic Research Papers, No. 867. The University of Warwick, September, Dublin. http://wrap.warwick.ac.uk/1349/1/WRAP_Crafts_twerp_867.pdf

Cullen, P. (2015): HSE Figures Show Lengthening Hospital Waiting Lists. The Irish Times, 29 January, http://www.irishtimes.com/news/health/hse-figures-show-lengthening-hospital-waiting-lists-1.2083227

EC (1998): European Economy, No. 66. European Commission, Belgium.

Encyclopaedia Britannica (s.a.) Ireland. History. https://www.britannica.com/place/Ireland/Sportsand-recreation\#toc214205

Esping-Andersen, G. (1990): The Three Worlds of Welfare Capitalism. Cambridge: Polity Press. 
Farkas, P. (1999): A gazdaságfejlesztő állam Írországban. (The developmental state in Ireland). Közgazdasági Szemle, 66(5): 470-482.

FitzGerald, J. (2013): The Effect of Redomiciled Places on GNP and the Irish Balance of Payments. ESRI (Economic and Social Research Institute) Research Notes. Quarterly Economic Commentary - Spring 2013. https://www.esri.ie/pubs/RN20130102.pdf

Forfás (2010): The Role of State Owned Enterprises: Providing Infrastructure and Supporting Economic Recovery. July, Dublin.

Giles, C. - Johnson, P. (1994): Taxes down, Taxes up: The Effects of a Decade of Tax Changes. The Institute for Fiscal Studies, London.

Glassner, V. (2010): The Public Sector in the Crisis. European Trade Union Institute. Working Paper, No. 07, Brussels. https://www.etui.org/Publications2/Working-Papers/Government-andtrade-union-responses-to-the-economic-crisis-in-the-financial-sector

Györffy, D. (2014): The Role of Expectations in Austerity Cycles: The Political Economy of Crisis Management in Ireland and Greece. Acta Oeconomica, 64(4): 481-509.

Glassner, V. - Keune, M. (2010): Negotiating the Crisis? Collective Bargaining in Europe during the Economic Downturn. Industrial and Employment. Relations Department International Labour Office. Geneva, March, Working Paper, No. 10.

GWL (2013): Great-West Lifeco Inc. Release. (A member of the Power Financial Corporation group of companies.) Winnipeg, July 18, 2013, https://www.greatwestlifeco.com/content/dam/gwlco/ documents/press-releases/2013/s7 031072.pdf

Hancock, C. (2014): IBRC Loan Sale Proceeds May Exceed €12.9bn. The Irish Times, April 25, http://www.irishtimes.com/business/financial-services/ibrc-loan-sale-proceeds-may-exceed-12 $-9 \mathrm{bn}-1.1773150$

Hancock, C. (2015): State's Holdings in Irish Banks Valued at $€ 16.4 \mathrm{bn}$, Says Noonan. The Irish Times, May 8, http://www.irishtimes.com/business/financial-services/state-s-holdings-in-irishbanks-valued-at-16-4bn-says-noonan-1.2204144

Hardiman, N. (2005): Partnership and Politics: How Embedded is Social Partnership? Geary Institute. Discussion paper Series, No. 2005/8.

Harris, C. - Carney, G. M. - Farrell, D. M. (2013): Rule by the People? Alternative Perspectives on Citizen Participation in Democratic Policymaking. Administration, 60(3): 201-209.

Hogan, J. (2010): Economic Crises and the Changing Influence of the Irish Congress of Trade Unions on Public Policy. In: Hogan, J. - Donnelly, P. - O'Rourke, B. (eds): Irish Business \& Society Governing, Participating \& Transforming in the 21st Century. Dublin: Gill \& Macmillan, Ch. 13.

Holland, K. (2015): Why are there More than 1,000 Homeless Children in Dublin? The Irish Times, July 4, http://www.irishtimes.com/news/social-affairs/why-are-there-more-than-1-000-homeless-children-in-dublin-1.2273119

Irish Life Group Limited (ILGL) (2012): Non-Statutory Interim Condensed Consolidated Financial Statements and Supplementary Embedded Value Financial Information for the Period Ended 30 June, http://www.irishlifegroup.ie/ /media/Files/I/Irish-Life-Group/reports-and-presentations/ ILG-Ltd-2012-Interim-Report.pdf

Kelly, F. - Taylor, C. (2015): Cabinet Agrees to Sell State's 25\% Stake in Aer Lingus. The Irish Times, May 26, http://www.irishtimes.com/business/transport-and-tourism/cabinet-agrees-tosell-state-s-25-stake-in-aer-lingus-1.2226921

Kirby, P. (2002): The Celtic Tiger in Distress. Growth with Inequality in Ireland. Palgrave McMillan. 
Kirby, P. (2009): The Competition State - Lessons from Ireland. Limerick Papers in Politics and Public Administration, No. 1. Department of Politics and Public Administration, University of Limerick, Ireland.

Leddin, A. J. - Walsh, B. M. (1995): The Macro-Economy of Ireland. Dublin: Gill and Macmillan.

Maurer, H. - Grussenmeyer, P. (2015): Financial Assistance Measures in the Euro Area from 2008 to 2013: Statistical Framework and Fiscal Impact. European Central Bank Statistics Paper Series, No. 7/April https://www.ecb.europa.eu/pub/pdf/scpsps/ecbsp7.en.pdf

McEnroe, J. - Connolly, S. - Rogers, S. (2015): Wage Hikes and Tax Relief on the Cards in New Pay Deal. Irish Examiner, January 20, http://www.irishexaminer.com/ireland/wage-hikes-andtax-relief-on-the-cards-in-new-pay-deal-307871.html

Milliken, D. (2015): Ireland Spent 37.3\% of GDP on Bank Bailout Costs. Irish Examiner, April 10, http://www.irishexaminer.com/business/mhowmhkfsnoj/rss $2 /$ ?utm_source=link\&utm_medium $=$ click\&utm_campaign $=$ sectionlink

Moya, E. (2009): Irish Government Faces Growing Fears of Debt Default. The Guardian, February 16, http://www.guardian.co.uk/world/2009/feb/16/ireland-debt-recession

Murphy, A. E. (2000): The 'Celtic Tiger' - An Analysis of Ireland's Economic Growth Performance. Robert Schuman Centre for Advanced Studies, European University Institute, Working Paper, No. 16, http://cadmus.eui.eu/bitstream/handle/1814/1656/00_16.pdf;sequence=1

National Asset Management Agency (NAMA) (2016): Annual Report and Financial Statements 2015. 12 May, https:/www.nama.ie/fileadmin/user_upload/5078_NAMA_AR2015_English_ screen-FINAL.pdf

National Asset Management Agency (NAMA Wine Lake) (2013): Does This Loophole Stop BoSi Enforcing Any Loans in Ireland Originally Advanced by ICC? 16 April, https://namawinelake. wordpress.com/2013/04/16/does-this-loophole-stop-bosi-enforcing-any-loans-in-ireland-originally-advanced-by-icc/

National Economic and Social Council (NESC) (1986): A Strategy for Development 1986-1990. Dublin, http://files.nesc.ie/nesc_reports/en/NESC_83_1987.pdf

National Economic and Social Council (NESC) (2005): The Developmental Welfare State. Dublin, $\mathrm{http}: / / w w w . s o c i a l i n c l u s i o n . i e / d o c u m e n t s / N E S C D e v e l o p m e n t a l W e l f a r e S t a t e . p d f$

Ó Riain, S. (2000): The Flexible Developmental State: Globalization, Information Technology, and the "Celtic Tiger". Politics \& Society, June, 28(2): 157-193.

O'Halloran, M. (2015a): Ireland will Not Agree to Railway Privatisation, Says Minister. The Irish Times, September 23, http://www.irishtimes.com/news/politics/oireachtas/ireland-will-notagree-to-railway-privatisation-says-minister- 1.2363998

O'Halloran, M. (2015b): NAMA Accused of Engaging in 'Fire Sales' of Assets. The Irish Times, June 16, http://www.irishtimes.com/news/politics/oireachtas/nama-accused-of-engaging-infire-sales-of-assets-1.2252040

Redmond, A. (ed.) (2000): That Was Then, This Is Now. Change in Ireland, 1949-1999. A Publication to Mark the 50th Anniversary of the Central Statistics Office. No. 8084, February, Government of Ireland, Dublin. http://www.cso.ie/en/media/csoie/releasespublications/documents/ otherreleases/thatwasthenthisisnow.pdf

Regan, A. (2012): The Rise and Fall of Irish Social Partnership. The Political Economy of Institutional Change in European Varieties of Capitalism. Amsterdam: Rozenberg Publishing Services.

Reuters (2014): Centrica Buys Irish Energy Supplier as Profits Sink at Home. Reuters.com, March 25, http://www.reuters.com/article/2014/03/25/us-centrica-bordgais-idUSBREA2O0F420140325

RTÉ (2011): Anglo Reports Record Corporate Losses. RTÉ News, March 31, http://www.rte.ie/ news/2011/0331/299310-anglo/ 
RTÉ (2013): 180 ACC Bank Jobs to Go in Services Withdrawal. RTÉ News, October 25, http:// www.rte.ie/news/2013/1025/482634-accbank/

Siegmund, U. (1996): Are There Nationalization-Privatization Cycles? - A Theoretical Survey and First Empirical Evidence. Kiel Working Paper, No. 757, https://www.econstor.eu/bitstream/10 419/46855/1/257762795.pdf

Teague, P. - Murphy, M. C. (2004): Social Partnership and Local Development in Ireland: The Limits to Deliberation. International Institute for Labour Studies, Discussion Paper Series, No.156.

TheJournal.ie. (2013): Explainer: What Happened Last Night? Why was IBRC Liquidated? What Happens Now? February 7, http://www.thejournal.ie/ibrc-liquidated-promissory-notes-ecbdebt-deal-786031-Feb2013/

TheJournal.ie. (2014): Honohan "Not Happy" about Mortgage Sales to Vulture Funds. Business ETC, Apr 30 ${ }^{\text {th }}$, http://businessetc.thejournal.ie/honohan-vulture-funds-ibrc-warning-1441483Apr2014/

TheJournal.ie (2015a): Revealed: Less Than Half of Irish Water Customers have Paid Their Bills. July 14, http://www.thejournal.ie/irish-water-payments-2216990-Jul2015/

TheJournal.ie (2015b): Ireland's Railways could be the Next up for Privatisation... July 30, http:// www.thejournal.ie/railway-tender-2243895-Jul2015/

The PB Report 2015/2016. A Publication of the Privatization Barometer. Fondazione Eni, Enrico Mattei, KPMG. www.privatizationbarometer.net

The Telegraph (2010): Anglo Irish Bank Bailout: Timeline. September 30, http://www.telegraph. co.uk/finance/newsbysector/banksandfinance/8034225/Anglo-Irish-Bank-bailout-timeline.html

Ward, J. (2017): Water Charges could Return through Back Door after Fianna Fail U-Turn. Irish Mirror, April 12, http://www.irishmirror.ie/news/irish-news/water-charges-could-returnthrough-10208443

White, D. (2016): Doing the Maths: How Real is Ireland's Economic Growth? Independent.ie, January 3, http://www.independent.ie/business/irish/doing-the-maths-how-real-is-irelands-economic -growth-34331206.html

Williams, P. (2013): Inside Anglo: The Secret Recordings. Independent.ie, June 24, http://www. independent.ie/business/irish/inside-anglo-the-secret-recordings-29366837.html 